\title{
Jurisprudencia comentada
}

\author{
Juan García Montúfar Sarmiento \\ Alumno del $6^{\circ}$ ciclo de la Facullad de Derecho de la \\ Pontificia Universidad Católica del Perú.
}

\section{RESOLUCION SUPREMA}

Lima, primero de marzo de mil novecientos setentiseis.- VISTOS Y CONSIDERANDO; que si bien la compra-venta de inmuebles se perfecciono por el consentimiento, sólo surte efectos frente al inquilino cn una acción de aviso de despedida cuando se lu uta de un inmuluble inscrito en los Registros Públicos si la traslación de dominio ha sido inscrita en favor del actor; que segin aparece a fojas setchtiocho, la cscritura de compra-venta del inmucble sub-litis, se celcbró en fecha posterior a la de interposición de la demanda y no se ha acreditado en autos que el inmucble se cncuentre inscrito a favor de la demandante en los Registros Públicos: declararon HABER NULIDAD en la sentencia de vista de fojas ciento veinte, su fecha ocho de Encro del año en curso, que confirmando la de primera instancia de fojas noventisicte, fechada el sicte de Noviembre último, declara fundada la demanda de fojas seis reformando la primera y revocando la segindo: declararon INFUNDADA la referida demanda de aviso de despedida interpuesta por doña Ann Jessica Eskenasi Delander contra doña Daria Salazar de Bayson, y los devolvieron (Fdo.) Figallo Adrianza. - García Montúfar. - Tolentino Tapia. - Tovar Velarde.

La jurisprudencia objeto de comentario establece un requisito previo para la interposición del aviso de despedida, la inscripción del dominio del propietario del inmueble arrendado. Dicho requisito se justifica en la necesidad de la inscripción registral para que el derecho de propiedad sea oponible a terceros, "... (sea) erga omnes, esto es, se pucda oponer a todos y (excluir) de su ámbito a todo otro titular"1. Esta tendencia jurisprudencial se ha mantenido hasta la fecha e inclusive se ha acentuado, puesto que muchos jucces consideran la inscripción de la traslación de dominio como un requisito de admisibilidad de la acción de aviso de despedida, por lo que no admitcn a trámite la acción si no se prucba la inscripción del dominio del actor.

No obstante, la legislación nacional adoptó sicmpre el principio según el cual la propiedad se transmite por el solo consenso, por lo que la citada jurisprudencia parecería vulnerar este sistema de transferencia de la propicdad.

Para entender la relación existente entre el requisito de la inscripción y la transmisión por el solo consenso, analizaremos dos puntos primordiales: primero, qué se entiende por derccho de propicdad

1. Avendaño V., Jorge: en Para leer el Código Civil. p. 103. y, segundo, cómo opera la transmisión sólo consenso.

Mazcaud define el derecho de propiedad, a partir del art. 544 del C.C. francés, como "... el derecho real más perfecto, el que confiere todos los poderes sobre la cosa que sea su objeto..." ${ }^{2}$; por su parte Barbero subraya lo absoluto de este derecho al señalar que está "...caracterizado su poder mientras no encuentre la resistencia de un límite legal o la concurrencia de otros derechos".

Este derecho "... en virtud del cual una cosa, como pertenencia de una persona, está enteramente sujcta a su voluntad..." ${ }^{4}$ tiene cuatro caracteres fundamentales que lo distinguen de los demás derechos reales "... es un derecho real, es un derecho exclusivo, es un derecho absoluto y es un derecho perpetuo" 5 . Nuestro análisis se centrará en el tercer carácter del mencionado derecho real, el ser absoluto y por tanto conferir "... a su titular todas las facultades po-

2. Mazeaud, IIcnry, Jcan y Lcón: "Lecciones de Derecho Civil.". Parte II, Vol. IV. p. 12.

3. Barbero, Doménico: "Sistema del Derecho Privado" T. 2 p. 218.

4. Barbero, Doménico: Ob. Cit. T. 2 p. 218.

5. Avendaño, Jorge: Ob. Cit. p. 103. 
sibles sobre el bien" ${ }^{6}$, puesto que parccería, según la interpretación jurisprudencial, que la propiedad transmitida por el sólo consenso carece de este carácter en vista que no contempla la facultad de plantear el aviso de despedida.

El derecho de propiedad es considerado como absoluto porque confiere a su titular todos los atributos relativos al bien (usar, disfrutar, disponer y reivindicar); por esta razón, el propietario de un bien inmueble que fuese titular de un verdadero derecho de propiedad, estaría en aptitud de plantear la acción de aviso de despedida a un inquilino que habitase dicho inmueble, para de esta manera habitar en el inmucble de su propiedad, es decir "... servirse del bien según su naturaleza" ${ }^{7}$ y cjercer así este cuarto atributo de la propiedad: reivindicar el bien.

Así, scría necesario analizar cómo opera la transferencia de propiedad por el solo consenso, para de este modo poder, asimismo, determinar si el derecho que se transfiere es o no un verdadero derecho de propiedad, que goce del carácter esencial de ser absoluto.

La transferencia de la propiedad por el solo consenso es definida por Rezzonico como un sistema"... según el cual y con relación a las partes la propiedad se transfiere por cl mero consentimiento o acucrdo de voluntades entre el enajenante y cl adquiriente..." ${ }^{8}$; por otra parte, para Castañcda "El contrato basta para producir este efecto, para transformar en propictario al acreedor" ${ }^{\prime \prime}$. Por tanto, en el momento en que las partes se ponen de acuer- do sobre cosa y precio se transmite al acreedor de la cosa - al menos dentro de esta opción- la propiedad de ésta. Sin embargo, el derecho de propiedad transmitido no corresponde con la definición de propiedad que dimos anteriormente, ya que "Las transmisiones de propicdad no son oponibles a terceros más que si han sido publicadas"10, entendiéndose por publicidad de la transmisión su inscripción en los Registros Públicos. Esta "limitación" a la transferencia por solo consenso, se basa en la necesidad de brindar seguridad y protección a terceros, quicnes sólo podrían conocer las transmisiones de propicdad si éstas se publicitan por algún medio, en este caso a travćs de su inscripción en el Registro de la Propiedad Inmueble.

En relación a lo antes expuesto, debemos concluir que el derecho transmitido vía el solo consenso dentro de nuestro sistema no es el derecho de propiedad estrictamente hablando, ya que no es oponible erga omnes y no es absoluto, en tanto no permite a su titular, por ejemplo, iniciar la acción de aviso de despedida, neccsaria para recupcrar el uso del bien en un caso de arrendamiento como el que venimos examinando.

Finalmente, creemos que debe considerarse al consenso como un simple título, puesto que no transfierc un derecho real estrictamente hablando, en tanto, que la inscripción debe entenderse como el modo en virtud del cual se transfiere al acreedor de la cosa el derccho de propicdad que le signifique poder ejercitar sobre el bicn "...la suma mayor de las facultades concedidas por la ley"11.

\section{Idem}

7. Castañeda, Jorge E.: "Instituciones del Derecho Civil." p. 204.

8. Rezzonico, Luis María.: "Estudio de los contratos". p. 17.

9. Castañeda, Jorge E.: Ob. Cit. p. 220.

10. Mazeaud, Henry, Jean y León: Ob. Cit. p. 322.

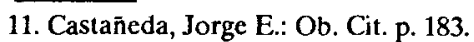

